\title{
The Myth of Right to Education
}

\author{
Dr. Pranita Choudhury \\ Asstt. Prof, University Law College Gauhati University, Guwahati 781014
}

\section{Introduction}

Education is a fundamental human right which is essential for the empowerment and development of an individual and the society as a whole. It is important for the exercise of all other human rights. It strengthens personal integrity and shapes the society in which we live. Education makes man civilized by making mankind literate in ethics and moral values. If we have a well nurtured and balanced education system, then half the task of the country's development is done. It promotes individual freedom and empowerment and yields important development and progress in the society. It is also an important instrument to reduce poverty.

Education supports a person's ability to access important information. But when there is no freedom of information regarding educational opportunities, the entire project of obtaining information is jeopardized. Lack of information can bar the economically disadvantaged from opportunities including educational facilities like various types of educational facilities, reservations- disabled quota and others. Many a times we see university seats go empty. This is not because of lack of opportunities but due to lack of awareness among the people and lack of transparency. Children's education in the middle and lower sections of society are discontinued due to inaccessible information. India despite being a signatory to numerous conventions and international declarations involving children's rights, funds obtained are not utilized mainly due to lack of awareness and lack of transparency.

Nelson Mandela said "Education is the most powerful weapon which you can use to change the world"1 In the words of Dr. Abdul Kalam Azad: "When learning is purposeful, creativity blossoms, when creativity blossoms, thinking emanates, when thinking emanates, knowledge is fully lit, when knowledge is lit, economy flourishes". ${ }^{2}$

\section{Right To Education And International Law}

The right to education is a universal entitlement to education, recognized in the International Covenant on Economic, Social and Cultural Rights as a human right that includes the right to free, compulsory primary education for all, an obligation to develop secondary education accessible to all, in particular by the progressive introduction of free secondary education, as well as an obligation to develop equitable access to higher education, ideally by the progressive introduction of free higher education. The right to education also includes a responsibility to provide basic education for individuals who have not completed primary education. In addition to these access to education provisions, the right to education encompasses the obligation to rule out discrimination at all levels of the educational system, to set minimum standards and to improve quality of education. The right to education is reflected in international law in Article 26 of the Universal Declaration of Human Rights and Articles 13 and 14 of the International Covenant on Economic, Social and Cultural Rights. The right to education has been reaffirmed in the 1960 UNESCO Convention against Discrimination in Education, the 1981 Convention on the Elimination of All Forms of Discrimination Against Women, and the 2006 Convention on the Rights of Persons with Disabilities. ${ }^{3}$

Education is a fundamental right. Article 26 of the Universal Declaration of Human Rights declares that-

(1) Everyone has the right to education. Education shall be free, at least in the elementary and fundamental stages. Elementary education shall be compulsory. Technical and professional education shall be made generally available and higher education shall be equally accessible to all on the basis of merit.

(2) Education shall be directed to the full development of the human personality and to the strengthening of respect for human rights and fundamental freedoms. It shall promote understanding, tolerance and friendship among all nations, racial or religious groups, and shall further the activities of the United Nations for the maintenance of peace.

(3) Parents have a prior right to choose the kind of education that shall be given to their children. 


\section{Right To Education And Indian Constitution}

Since the framing of the Indian constitution, the founding fathers had in their hearts a divine duty to uplift educational rights of the citizens. Since its origin educational rights were aimed to be given equally to all including minority community. The noble lines from a poem by Rabindra Nath Tagore quoted in H.M.Seervai's ' Constitutional law of India'. ${ }^{4}$

"None shall be turned away

From the shore of this vast sea of humanity

That is India"

The Constitution of India guarantees Cultural and Educational rights. Articles 29 and 30, ${ }^{5}$ are measures to protect the rights of cultural, linguistic and religious minorities, by enabling them to conserve their heritage and protecting them against discrimination.

The Constitution of India in its 'Preamble' has promised to secure to all citizens "Justice, social, economic and political", "Liberty of thought, expression, belief, faith, and worship".. It further provided "Equality of status and of opportunity" and assured dignity of the individual. The objectives flowing from the 'Preamble' cannot be achieved and shall remain on paper unless the people in this country are educated. Although 'right to education' had not been guaranteed as a fundamental right under Part III of the constitution, Articles 21,38, 39(a), 41 and 45 (in Part IV of the Constitution of India) together makes it clear that the framers of the constitution made it obligatory for the State to provide education for its citizens. Article 21 says "No person shall be deprived of his life or personal liberty except according to procedure established by law". The right to life under Article 21 and the dignity of an individual cannot be assured unless it is accompanied by right to education. Therefore, every citizen has a 'right to education' under the constitution and thus, the state had an obligation to provide educational institutions at all levels for the benefit of all the citizens. All educational institutions whether it is state owned or state recognized are obliged to secure the right to education'.

The Government of India launched the Right to Education Act in 2009 making education a fundamental right and making education free and Compulsory up to 14 years of age. It was a long demand of the people of India making many in the country heave a sigh of relief. Right to Education was simply enshrined in the Directive Principles of our Constitution as something that remained ornamental. Recently, the National Commission for Human Rights gave a stricture to one of the State Governments to immediately redress the problems of street children through education and proper care. Thus, RTE is not a simple position, it involves a whole lot of other complex questions such as rehabilitation, socio-economic development, and education for all. $^{7}$

In Mohini Jain vs. State of Karnataka ${ }^{8}$, the Supreme Court passed a historic judgment declaring the 'right to education' as a fundamental right in 1992. On 4th. August 2009 the Right to Education was passed by the Parliament of India to guarantee free and compulsory education for children between 6 and 14 years under Article 21a of the Indian Constitution. Article 45 originally mandated the state to provide free and compulsory education to children between the ages of six and fourteen years.

\section{Corruption Is A Cancer Which Diverts Education}

Corruption is a universal disease causing harm to the people and government almost everywhere in the world. Political leaders have expressed their helplessness to contain corruption by arguing that corruption is a worldwide phenomenon. Corruption undermines development. It is ugliest when corruption seeps into social sectors especially education and the cost is enormous. The education sector is very delicate as we are preparing our children with the basic skills to secure their future- good jobs, care for their families and above all become good citizens. Corruption diverts the sources from the poor to the rich. It is the major barrier to development. It restricts services to the most vulnerable and poor people. In short corruption is stealing from the poor. It steals promises of a brighter future.

Mahatma Gandhi, May 1939 said "I would go to the length of giving the whole congress a decent burial, rather than put up with the corruption that is rampant." The cost of corruption is high. Every year billions of rupees are stolen and the poor beneficiaries are deprived. Stolen resources from education budgets mean overcrowded classrooms and crumbling schools, or no schools at all. Books and supplies are sold instead of being given out freely. Schools and university authorities sell, rents out school properties and earns money without maintaining account. Unauthorized fees, forcing students to drop out. Teachers and lecturers without proper qualifications are appointed through family connections, or by taking bribes. Low quality teachers are appointed in colleges and universities managing them with low salaries. Teachers force students to pay for tuition outside class. In higher education, undue government and private sector influence adversly affect research agendas. Ultimately the end result is limited access, opaque system and lack of transparency.

Noted scientist and educationist Prof. Yash Pal said "large-scale corruption is prevalent in the education system..." Corruption is said to be a "Hidden', 'Occult' and 'Immoral' phenomenon. ${ }^{9}$ The World 
Bank defines corruption as the abuse of public power for private benefit, and such a definition is widely accepted partly because it is relatively neutral as between different states, allowing cross-state comparisons. Robert Klitgaard (1988) correctly puts up, 'Monopoly + Discretion - Accountability = Corruption'.${ }^{10}$ Corruption of this type is ineradicable, though it may be greater or smaller in different states of the country, corruption is spread all over in the society in several forms. It has been observed that in the academic regulatory bodies corruption has reached its climax. If corruption continues to be the rule of these regulatory bodies then development in education cannot be expected. Corruption in the education sector not only distorts efficiency and quality parameters but also acutely constrains social equity by making higher education out of the reach of the common people. These distortions certainly come in the way of realising the cherished objective of inclusive growth. The first tremor in the education sector came in the form of the deemed university status. It is found that in many cases the status was granted in gross violation of the UGC norms.

The Tandon Committee constituted by the Human Resource Development Ministry to investigate the deemed university scam has found that, out of the 130 deemed universities, 44 had abysmal academic and physical infrastructure and are mainly family fiefdoms. On the recommendations of the Tandon Committee, the HRD Ministry derecognized 44 deemed universities. The case of the derecognized deemed universities, having two lakh students on their rolls, is pending in the Supreme Court.

Another sensational news is that the All India Council of Technical Education scam, the CBI has completed its probe in about 200 complaints. The agency found that 42 institutes were granted illegal approval by the AICTE. In a glaring case the agency detected that one building was inspected by the experts appointed by the AICTE thrice and recommended approval for three different colleges for the same building. A few inspection committees did not visit the site of the proposed colleges but submitted their reports. The AICTE scam is so large that 17 Criminal Bureau of Investigation branches are investigating it.

The Medical Council of India also has a dubious record for granting approval to medical colleges. The MCI President was arrested recently for accepting a bribe of Rs 2 crores. According to reports, the CBI in its recent raids found that the former President of the MCI and his family possessed disproportionate assets worth Rs 24 crore. A good development is that the President of India has dissolved the MCI and replaced it by a sixmember Board of Governors.

The managements of these corrupt educational institutions recover the bribe money from students by charging high fee and unauthorized charges. The Tandon Committee has reported that many deemed universities have been charging fee much higher than that approved by the official fee structure committees. The practice of charging exorbitant fee and unapproved charges denied the less privileged segments of society like the poor, SCs and STs, women, and rural students access to higher education, thus making professional education less inclusive. Klaus Dieter Beiter in his book 'The Protection of Right to Education by International Law' describes commercialization of education, excluding the poor from access to education. ${ }^{11}$ The quality of education is another casualty of corruption. For the institutions getting approval by corrupt practices, making money is the sole mission. These greed-centric institutions thrive on unethical practices and are virtually degree printing machines having no correlation whatsoever with quality. The ill-baked products of these institutions in no way can help the nation build a knowledge-based economy. Now it is the duty of the state and the government to protect and enrich the right to education, but they too do not know what is expected of them when realising the right to education.

Prime minister Dr.Manmohan Singh in his address at $150^{\text {th }}$ anniversary function of university of Mumbai said "Our university system is, in many parts, in a state of disrepair...In almost half the districts in the country, higher education enrollments are abysmally low, almost two-third of our universities and 90 per cent of our colleges are rated as below average on quality parameters... I am concerned that in many states university appointments, including that of vice-chancellors, have been politicised and have become subject to caste and communal considerations, there are complaints of favouritism and corruption" $(2007)^{12}$

Arindam Choudhury, Head of the Indian Institute of Planning and Management (IIPM) decried that UGC and AICTE are "full of bribe seeking corrupt officials" Reported in India Today. ${ }^{13}$ The Telegraph July $17^{\text {th }} .2009$, states that a bribery scandle is unfolded at the AICTE for allegedly accepting Rs.5 lakhs as first installment of Rs 20 lakhs for granting recognition to an engineering college at Hydrabad. ${ }^{14}$

The Tandon Committee has found that many universities have violated the norms - firstly, they violated the guidelines prescribing excellence in teaching, research and innovations and are basically running unrelated programmes accompanied by thoughtless teaching pedagogy. Secondly only a few private deemed universities supplied evidence of good quality research, especially in the form of publications in high impact journals. Thirdly, these institutions hardly recruit meritorious faculty. A skeleton and under-qualified faculty is the general norm. The qualified faculty, if any, is under-paid and does not enjoy job security benefits. The talented faculty is perceived as a threat to the unethical practices followed by these institutions. 
Fourthly, for want of quality products of these institutions are hardly employable. These institutions thus in the long run may add to the frustration of youth in the country which may erupt like a volcano at any time.

Education in India is primarily a state-sponsored activity, the funds for education in India comes mainly from the government sources: the central and state governments are the major partners in financing education. Education used to be the responsibility of the state governments and at present it is a joint responsibility. Even then a substantial proportion of the resources for education come from the state governments which expect devolution of a larger share of resources from the central government. Besides, there is competition among the states to get larger shares of the central resources. Since the cake from which the state's share of education is to be sliced is very small, this competition sometimes results in confrontation between state governments and central government on the question of the devolution of resources. More often than not, the resources actually made available to education are more a reflection of the interplay of various forces at different levels of governmental controls than any sound economic or investment criteria. While the pattern of devolution of resources may indirectly ensure the national priorities in education, its actual utilisation is the responsibility of the state government. The multi-level structures of planning and management within the federal framework therefore becomes crucial in the allocation and utilisation of resources for education in India. There are multiple sources of finances for education in India. These sources can be broadly classified into external and internal or domestic sources of financing. External sources do not form a significant part of educational finances in India. The domestic sources of funding are broadly divided into public and private sources. The public sources include contributions made by central, state and local governments. The private or non-governmental sources include fees and other household expenditures incurred by the direct beneficiaries (students/parents) of education and endowments and donations made by individuals, trusts, etc. Among the private sources, fees are a compulsory payments whereas others are voluntary contributions. Financing in the educational system is no problem but what is wanted is constant vigilance of utilization of the funds and proper accounting.

\section{Salient Features Of The Right To Education Act -}

1. The Act makes it incumbent on all the States to provide free and compulsory education to children in the age group of 6-14 years. Private schools will have to take $25 \%$ of their class strength from the weaker section and the disadvantaged group of the society through a random selection process. Government will fund education of these children.

2. No donation and capitation fee can be charged from children. Collection of capitation fee will attract a fine of up to 10 times the amount collected.

3. No child from disadvantaged groups to be denied free education.

4. No screening test, admission test or interview either for child or parents.

5. No child can be held back, expelled from school.

6. National and State Commission for protection of Child Right would monitor the effective implementation of the measures in the Act and inquire into complaints.

7. Quality teachers are recruited. Norms for teachers training and qualifications are also clearly mentioned in the act. Untrained teachers would have to upgrade themselves in five years.

8. No non-teaching work can be given to teachers.

9. Any corporal punishment is unlawful.

10. Schools will maintain 1:40 teacher student ratio.

11. All schools have to adhere to rules and regulations laid down in this act, failing which the school will not be allowed to function. Three years moratorium period has been provided to school to implement all that is required of them.

12. All schools except private unaided schools are to be managed by School management Committees with $75 \%$ of parents out of which $50 \%$ to be women members.

"The right to development is an inalienable human right by virtue of which every human person and all people are entitled to participate in, contributing to, and enjoy, economic, social, cultural and political development, in which all human rights and fundamental freedoms can be fully realized." 15 Prior to the adaptation of this Declaration, human rights were recognized as rights so fundamental to every person that their violation could lead to the disintegration of societies. By locating the right to development in a human rights framework therefore, the Declaration sought to place the developmental process on the same pedestal, ensuring that nations were in fact, obligated to implement policies that would lead to growth and development. ${ }^{16}$

Human Rights include various rights, like right to health, right to life, right to freedom or right to education. The right to education is one of the most essential right without which the society cannot develop in its true sense. True human values are inculcated in a person through proper education. Therefore right to education is one of 
the basic right. In the last decade, countries across the globe, including India, have been making a conscious effort towards improving the educational status of their citizens. What was earlier only a policy goal, has in recent times, taken shape as a right instead. ${ }^{17}$ The main reason for this has been the emergence of the human rights approach towards education. It was realised that in order to give priority to educational goals, States must be obligated to ensure implementation of educational policies and a human rights framework was ideal for this. Thus right to education began to be seen as an inviolable human right, placing a duty upon States to take appropriate steps towards its fulfillment.

\section{Conclusion}

The government of India took more than sixty two years to realize the importance of providing free education to every child. This Right to free and compulsory education Act 2009, is certainly a historic step towards progress, but without wholehearted cooperation of the government and the people and efficient working in getting it implemented, things would not change much. Transparency in education is also an essential step towards improving the society. If there is transparency in the educational sector, the disadvantaged and deprived will get their due. The Right to education is a great step which brings the country closer to achieving the objectives and mission of developmental goals in India. The new NDA government is framing a new educational policy to remove the existing loopholes and give maximum and easy access to better education to all sectors of the society. This Right was enacted with the objective of providing universal elementary education and provide free and compulsory education to all but due to the short comings and corrupt practices it is still a myth and not a reality. This Act will also be a decorative ornament in the statute books if not implemented in the right direction. Right to education will remain a myth rather than a reality.

\section{References}

[1]. Nelson Mandela, July $16^{\text {th }} .2003$ University of Witwatersrand, Johannesburg, South .Africa.

[2]. APJ Kalam (2006) Indomitable Spirit, Rajpal and Sons, N Delhi.

[3]. http://en.wikipedia.org/wiki/Right to education Accessed on 14/11/14

[4]. H.M. Seervai. Constitution of India. $4^{\text {th }}$ edition. vol 2, Universal Book Traders, Delhi (1999).

[5]. Ibid. P.1309

[6]. Preamble to the Constitution of India

[7]. http://www.merinews.com/article/right-to-education-myth-or-reality/15866268.shtml\#sthash.AGpFaQuH.dpuf

[8]. Mohini Jain vs. State of Karnataka,1992 AIR 1858

[9]. Dieter Haller \& Cris Shore, Corruption, Anthropological Perspectives. (2005), p.11

[10]. Ibid, p.69

[11]. Klaus Dieter Beiter, 'The Protection of Right to Education by International Law' International studies in HumanRights.

[12]. Dr. Manmohan Singh (2007) $150^{\text {th }}$ anniversary function of university of Mumbai.

[13]. India Today -February17, 2013

[14]. The Telegraph July 17,2009 (Calcutta edition)

[15]. Art. 1 Declaration on the Right to Development, General Assembly Resolution 41/128 (Adopted in December 4, 1986).

[16]. Arjun Sengupta, The Right to Development and Human Rights in Development, presented at $125^{\text {th }}$. Nobel Symposium on a Human Rights Approach to Development and the Right to Development ( Oslo, Norway, October 13-15, 2003)

[17]. C. Raj Kumar, International Human Rights Perspectives on the Fundamental Right to Education - Integration of Human Rights and Human Development in the Indian Constitution, 12 Tulane Journal of International and Comparative Law 237 (2004) 